Intersections

Canadian Journal of Music

Revue canadienne de musique
Intersections CANADAN TOURAA OP NUSIC

Michela Niccolai. 2012. Giacomo Puccini et Albert Carré: 'Madama Butterfly' à Paris. Turnhout: Brepols. 332 pp. ISBN: 978-2-503-54761-9

\title{
Helen Greenwald
}

Volume 35, numéro 1, 2015

URI : https://id.erudit.org/iderudit/1038952ar

DOI : https://doi.org/10.7202/1038952ar

Aller au sommaire du numéro

Éditeur(s)

Canadian University Music Society / Société de musique des universités canadiennes

ISSN

1911-0146 (imprimé)

1918-512X (numérique)

Découvrir la revue

Citer ce compte rendu

Greenwald, H. (2015). Compte rendu de [Michela Niccolai. 2012. Giacomo Puccini et Albert Carré: 'Madama Butterfly' à Paris. Turnhout: Brepols. 332 pp. ISBN: 978-2-503-54761-9]. Intersections, 35(1), 172-177.

https://doi.org/10.7202/1038952ar

Copyright @ Canadian University Music Society / Société de musique des universités canadiennes, 2016
Ce document est protégé par la loi sur le droit d'auteur. L'utilisation des services d'Érudit (y compris la reproduction) est assujettie à sa politique d'utilisation que vous pouvez consulter en ligne.

https://apropos.erudit.org/fr/usagers/politique-dutilisation/ 
Pasler, Jann. 2009. Composing the Citizen: Music as Public Utility in Third Republic France. Berkeley and Los Angeles: University of California Press.

Russell, Dave. 1987. Popular Music in England, 1840-1914: A Social History. Montreal: McGill-Queen's University Press.

Weber, William. 2008. The Great Transformation of Musical Taste: Concert Programming from Haydn to Brahms. Cambridge: Cambridge University Press.

\section{BIOGRAPHY}

David Gramit teaches musicology at the University of Alberta. His current research focuses on settler colonialism and music in early Edmonton, and together with Mary Ingraham, he is also involved in developing both print and online collections of sources for the history of music in Canada.

Michela Niccolai. 2012. Giacomo Puccini et Albert Carré: 'Madama Butterfly' a Paris. Turnhout: Brepols. 332 pp. ISBN: 978-2-503-54761-9.

One way of tracking the life of an opera is through the legacy of its genesis and performance history (see, for example, Baker 2013 and Syer 2014). Such a paper trail could include financial records, drawings of sets and costumes, testimony of witnesses, and, of course, librettos and musical scores. In the nineteenth century, composers and publishers began to record the details of performances-placement of scenery and props, movement on stage, and certain aspects of lighting, all often coordinated with the libretto-in production books. This type of record keeping is a manifestation of a number

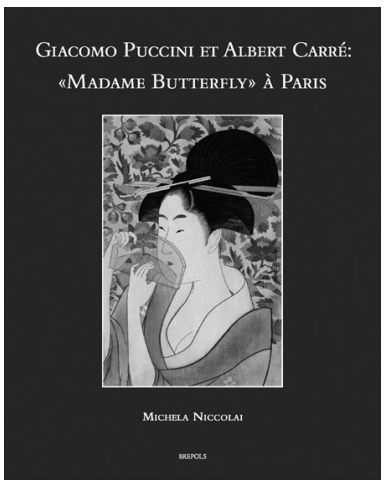
of factors, including a growing interest in posterity, and questions of ownership, transmission, and reproduction. Production books could preserve the past, secure rights, and promote different kinds of truths; they offered detail beyond the relatively sparse instructions that might appear in scores and librettos. Production books could also transmit an imagined single, "correct" or "authoritative" version of the staging of a work, making it possible, as James Hepokoski has pointed out in the case of Verdi, "to see the same La forza del destino ... that Verdi himself saw-or visualized-at [its] premiere" (see Hepokoski in Latham and Parker 2001: 11, and Hepokoski et al: 2001: 11-48, a roundtable on staging). The immediate and less obviously self-serving goal of such documents was to facilitate later performances, locally and internationally, to insure their "fidelity" to the composer's and director's intentions and also curb the impulses of future stage directors, who might be tempted to stray from an "official" text. In the late twentieth and twenty-first centuries, staging practices reveal a distinct rebellion against the notion of a 
fixed text, sometimes deemed "status quo" or "party line." Critics such as Alex Ross in The New Yorker have denounced productions that uproot perceived intentions of composers and librettists (see Ross 2004 and Mueller 2014: 582-605, especially $588-589$ ).

There are production manuals for eight of Giacomo Puccini's twelve operas: Manon Lescaut, La bohème, Tosca, Madama Butterfly, La fanciulla del West, Il tabarro, Suor Angelica, and an additional document for Turandot, that is not exactly a staging manual, but a printed score with markings, stage directions, and additional prose indications for performance pasted in for Act III finale (see Greenwald, 2011-). These manuals are important for many reasons, not least because Puccini was a visual composer whose spirit more often than not manifested itself in a place: Paris, the Port of Le Havre, the California Sierras, Nagasaki at the turn of the twentieth century, Rome in 1800, and Florence in 1299, just to name a few. One might think of him as an early film director, who goes "on location," whose operas contain a large proportion of instrumentally accompanied action sequences (the "Vigil" scene in Madama Butterfly is one of the most well-known). Most of all, Puccini, interested in realism, always searched for ways to make the theatrical experience life-like by responding musically to what he himself saw. He was visionary about when to drive the moment with words and when to allow action to take over, strategizing in ways that would eventually be routine for a film director. It's no small wonder that twice in his life he was inspired by the work of American playwright and stage director David Belasco, whose one-act play, Madame Butterfly and its innovative "Vigil" scene were the cornerstones of Puccini's opera. It's all the more remarkable that when Madama Butterfly failed to please at its first performance, it was a stage director who played the greatest role in its revival: Albert Carré, whose production book for the December 28, 1906 premiere at the OpéraComique of the revised Madama Butterfly is the focus of Michela Niccolai's beautifully written and organized and wonderfully substantive book.

Niccolai organizes her volume into four main sections: a history of the genesis of the new Madama Butterfly production for Paris, a discussion of the Japanese elements in the opera and the sources for them that molded the Paris production, a detailed explanation of the sources used for the edition of the production book, and an annotated edition of the document itself, fully reproduced. There are six appendices that contain a treasure trove of details about lighting and costumes in the available sources. Niccolai also describes the collections that house the sources that were used in the edition. There are several copies of Carré's production book as well as related documents in the Bibliothèque de l'Association de la Régie Théâtrale (ART) in Paris, which have been catalogued by H. Robert Cohen and Marie-Odile Gigou (1986: 144-146) The ART together with the Bibliothèque Historique de la Ville de Paris (BHVP) and the Bibliothèque-musée de la Comédie-Français (BMO) house an extraordinary number of documents, including mise-en-scènes, manuscripts, prints, librettos, and scores for hundreds of stage works premiered between 1830 and 1930 (Niccolai 105). Among the most important of these items are "working scores," annotated on a daily basis by the directors and conductors who used 
them when mounting a work for the stage (107). Niccolai categorizes the various sources for her edition as follows: handwritten annotations on leaves inserted between the pages of a printed libretto, handwritten annotations on leaves inserted between pages of a printed score, and production books (two in manuscript form and one printed). Collectively, these documents define the labour behind the Paris Madama Butterfly.

In the first section of her introduction, Niccolai shows the importance of historical context for understanding both the history of operatic production books-the livrets in France and disposizioni sceniche in Italy-as well as that of Puccini's opera. Of particular interest is her assertion that the advent of the production book signaled a type of "industrialization" (2) of the theatrical system, specifically insofar as the document represents a prescription for the scenic details - coordinated precisely with the libretto-of a single production of an opera "approved" by the composer, and, of course, the publisher. Niccolai devotes the next section of the introduction to the genesis and production of Madama Butterfly, citing letters that pertain specifically to the opera's mise-enscène. Most of this, however, is a review of an already well-documented story (see Groos, Bernardoni, Ravenni, et al 2005; Schickling 1998; Girardi 2000: 247-257; Groos 1994; and Viale Ferrero 1998). The next section leads the reader closer to the subject at hand, Puccini, Carré, and the 1906 Paris production.

Carré had begun his association with the Parisian operatic milieu with $\mathrm{La}$ bohème in 1898 and soon thereafter directed two world premieres: Charpentier's Louise (1900) and Debussy's Pelléas et Mélisande (1902), which was Carré's initiation into the Parisian operatic constellation (Girardi 2000: 247). By the time Madama Butterfly became a subject of discussion for Paris, it had suffered a disastrous premiere at La Scala (17 February 1904), after which the opera was withdrawn, revised, and freshly presented at the Teatro Grande in Brescia (28 May 1904). That was by no means the end of Puccini's tinkering with the opera. Dieter Schickling (1998: passim) argues that no single version of the opera can stand as definitive. Puccini connected with Carré through Tito Ricordi, who had taken a firm approach with the composer regarding revisions. Puccini appreciated Carré's expertise, and on 13 July 1906 wrote to his friend Sybil Seligman of his satisfaction with the process: "I have fixed Butterfly definitively [...]. The director of the opera, Carré, will do a special, very original staging [...]. It is the first opera in Japanese costume ever to be done at the Opéra-Comique" (Gara 1958: letter n. 479, 323-324; see also Girardi 2000: 240). What most witnesses to the proceedings and its outcome agree upon is the attention Carré lavished on both the dramatic logic of the libretto and its Japanese aspects. In fact, Luigi Illica went to Paris to work on the Italian translation of the adjusted libretto and was very pleased with Carrés unfolding realization of the opera. As he wrote to Ricordi on 8 December, the staging is "for the most part [...] logical, practical, and poetic" (Gara 1958: letter 497, 335-337). Niccolai's background material concerning Carré and his connection to Japonaiserie is one of the most interesting and successful sections of her book. Here she identifies relevant correspondences between the set and props of Madama Butterfly and Carré's experience with orientalist subjects, beginning with his collaboration 
with André Messager on Madame Chrysanthème and continuing with the production Puccini's Madama Butterfly in London where Messager headed the Royal Opera.

Another important player in the genesis of the Paris production of Madama Butterfly was Albert Kahn. Kahn, a French banker and philanthropist, besotted by Japan on a first visit, returned with a fierce determination to construct a stylistically diverse garden-Jardins $d u$ Monde-at his residence in BoulogneBillancourt. An entire section of the garden devoted to Japan included two authentic cottages constructed of wood and rice paper by a Japanese carpenter; bonsai trees planted in "vases made of precious Japanese ceramic" defined the landscaping around the cottages (15). Wonderful color photos of the garden from the Musée Albert-Kahn in the Département des Hauts-de-Seine may be found on pages 91-93. The set designers Marcel Jambon and Alexandre Bailly modelled the decorations in Cio-Cio San's house after those in Kahn's maisonettes.

Niccolai then compares the Paris production with the Milanese original followed by a discussion of the logic of the mise-en-scène, and sections on the flower duet, the intermezzo, and Carrés interest in coordinating musical and scenic aspects of the opera. The opening of the "musical" section concludes with an overview of critical reaction to the work.

Ricordi published Carrés mise-en-scène in 1906 and a few years ago made available a scanned copy of it, which is easily obtained online (Carré 1906). The scanned copy is, however, one of several different incarnations of the book, among which there are only minor differences, as Niccoali points out in her annotations. It is sometimes difficult to term these annotations "critical notes" because they often depart from and step beyond the strictly editorial relevance of a more rigorous exercise in textual criticism; mixed in with traditionally critical notes are a plethora of valuable observations, definitions of Japanese terminology regarding screens, vases, and such, and references to scholarly sources. But this point about nomenclature would not be mentioned at all had the words "critical edition" not been used to define what is otherwise a very finely executed and important volume that any Puccini scholar or enthusiast would be very happy to have.

Helen Greenwald

\section{BIBLIOGRAPHY}

Baker, Evan. 2013. From the Score to the Stage: An Illustrated History of Continental Opera Production and Staging. Chicago: University of Chicago Press.

Carré, Albert. 1906. Milan: Ricordi. Available online: http://www. internetculturale.it/opencms/opencms/it/viewItem Mag. jsp? case $=\& \mathrm{id}=\mathrm{oai} \% 3 \mathrm{Aww}$.internetculturale.sbn.it\%2FTeca\%3A20\%3AN Toooo\%3AMIo285_DISP_SCEN_06-01 (accessed January 30, 2016).

Cohen, H. Robert, and Marie-Odile Gigou. 1986. Cent ans de mise-en-scène en France (env. 1830-1930). New York: Pendragon. 
Gara, Eugenio, ed. 1958. Carteggi Pucciniani. Milan: Ricordi.

Girardi, Michele. 2000. Puccini: His International Art, trans. Laura Basini. Chicago: University of Chicago Press.

Greenwald, Helen. 2011-. "Puccini." In Oxford Bibliographies Online: http:// www.oxfordbibliog raphies.com/view/document/obo-9780199757824/ obo-9780199757824-0026.xml?rskey=ZZfdij\&result=65 (accessed January 30, 2016).

Groos, Arthur. 1994. "Lieutenant F.B. Pinkerton: Problems in the Genesis and Performance of Madama Butterfly." In The Puccini Companion, edited by William Weaver and Simonetta Puccini, 169-201. New York: Norton.

Groos, Arthur, Virgilio Bernardoni, Gabriella Biagi Ravenni, and Dieter Schickling, eds. 2005. Madama Butterfly: fonti e documenti della genesi, preface by Bruno Ermolli. Lucca: Centro studi Giacomo Puccini; Lucca: Maria Pacini Fazzi.

Hepokoski, James. 2001."Staging Verdi's Operas: The Single 'Correct' Performance." In Verdi in Performance, edited by Alison Latham and Roger Parker, 11-22. New York: Oxford University Press.

Hepokoski, James, Andrew Porter, David Rosen, et al. 2001. "Part I: Staging" [a roundtable of individual contributions]. In Verdi in Performance, edited by Alison Latham and Roger Parker, 11-48. New York: Oxford University Press.

Mueller, Ulrich. 2014."Regie-Theater/Director's Theater." In The Oxford Handbook of Opera, edited by Helen M. Greenwald, 582-605. New York: Oxford University Press.

Ross, Alex. 2004. "Nausea: A New Parsifal at Bayreuth." The New Yorker (August 9)., Available online: http://www.newyorker.com/archive/2004 /08/o9/040809crmu_music1?currentPage=all (accessed January 30, 2016).

Schickling, Dieter. 1998. "Puccini’s 'Work in Progress': The So-Called Versions of 'Madama Butterfly," Music \& Letters 79/4: 527-537.

Syer, Katherine. 2014. "Production Aesthetics and Materials." In The Oxford Handbook of Opera, edited by Helen M. Greenwald, 531-552. New York: Oxford University Press.

Viale Ferrero, Mercedes. 1998. "Riflessioni sullescenografie pucciniane". Studi pucciniani 1: 19-42.

\section{BIOGRAPHY}

Helen Greenwald is chair of the Department of Music History and Musicology at the New England Conservatory in Boston. Her work on vocal music of the 18th - 2oth centuries has appeared in an international array of publications, including 19th-Century Music, Acta Musicologica, Journal of the American Musicological Society, the MozartJahrbuch, Cambridge Opera Journal, the Salzburger Akademische Beiträge, Music \& Letters, Nineteenth-Century Music Review, Current Musicology, The Cambridge Verdi Encyclopedia, The New Grove Dictionary of Music and Musicians, Oxford Bibliographies Online, and The Encyclopedia of New England Culture. She is the editor of the Oxford Handbook of Opera (Oxford University Press, 2014) as well as the critical editions 
of Verdi's Attila, premiered 2010 by Riccardo Muti in his debut at the Metropolitan Opera, and Rossini's Zelmira, premiered 2009 by Robert Abbado at the Rossini Opera Festival in Pesaro.

James Harley. 2015. Iannis Xenakis: Kraanerg. Landmarks in Music since 1950 Series. Burlington, VT: Ashgate. 153 pp. ISBN: 978-1-4094-2331-7.

This is the first English-language volume, to my knowledge, devoted to the examination of a single Xenakis piece. Kraanerg-a composite word made up of two other Greek words: 'kraan' (to accomplish or perfect) and 'erg' (energy or work) - seems ideally suited for this purpose: it is the longest piece Xenakis wrote, lasting some 75 minutes and integrating both acoustic instruments with electronics and music with choreography and, by extension, relatively complex staging. I should also, perhaps, confess that it happens to be my own favourite Xenakis piece, even though it remains one I have only experienced in recorded form. That my enthusiasm for Kraanerg (and Harley's too) was not mirrored

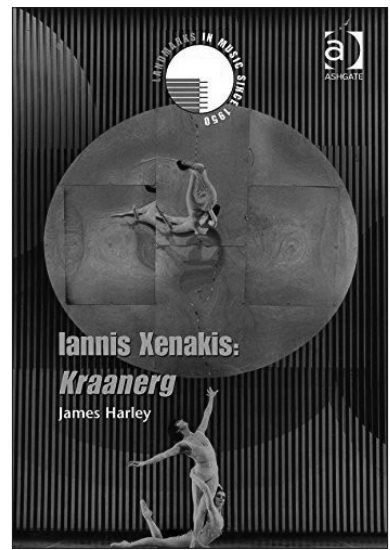
by Xenakis's own relationship with the piece makes this simultaneously a more exciting and more intriguing publication. Though it is a relatively slim volume-125 pages, once the bibliography is excluded-it has been a long time in gestation, the underpinning research going back to the mid-199os and perhaps earlier. Given Kraanerg's scale, and the dense network of media it deploys, Harley's task in covering it in so few pages is a difficult one, not least since the volume seems implicitly to set for itself the goal of using Kraanerg to introduce those (more or less) unfamiliar with Xenakis to his output while still providing sufficient depth to engage with the rich tradition, especially more latterly, of Xenakis scholarship in the writings of, amongst others, Benoît Gibson, Sharon Kanach, and Makis Solomos. The tension between these two poles seems to become periodically tangible within the volume and is not, to my mind, ever fully resolved: some of the volume is too simple for the expert, but too dense for the beginner. But these moments are relatively unusual; for the most part, Harley manages to steer precisely the perilous course between these two extremes with remarkable adroitness, such that there is matter here to engage a wide range of audiences.

Aside from a very brief introduction and nearly as terse an epilogue, the volume comprises six chapters. The first two essentially provide background, biographical and compositional, while the following four are devoted in succession to an historical examination of how Kraanerg came about, an analysis of the piece (at 50 pages, very much the heart of the book), an account of the 